\title{
Higher expression level of tyrosine kinase-like orphan receptor 2 and Wnt member 5a in papillary thyroid carcinoma is associated with poor prognosis
}

\author{
LIANG CHEN $^{1,2}$, LIANMEI ZHAO ${ }^{1}$, MINGJIAN DING ${ }^{2}$, MENG YANG ${ }^{2}$, \\ WENHUA YANG ${ }^{2}$, GUOZHONG CUI ${ }^{2}$ and BAOEN SHAN ${ }^{1}$ \\ ${ }^{1}$ Research Center, The Fourth Hospital of Hebei Medical University, Shijiazhuang, Hebei 050011; \\ ${ }^{2}$ Department of Oncology, Cangzhou Central Hospital, Cangzhou, Hebei 061001, P.R. China
}

Received January 21, 2016; Accepted June 16, 2017

DOI: $10.3892 / 01.2017 .6989$

\begin{abstract}
The tyrosine kinase-like orphan receptor2(ROR2) has a wnt-mediated, pro-tumorigenic role in certain types of cancer. The present study was designed to assess the protein expression level of ROR2 and its putative ligand Wnt member 5a (Wnt5a), as well as the association with clinicopathological features in papillary thyroid carcinoma (PTC). A total of 58 patients were recruited, resulting in 58 human PTC tissue samples and their paired adjacent noncancerous tissue samples being obtained. The protein expression levels of ROR2 and Wnt5a were evaluated by immunohistochemistry and western blotting, and messenger RNA expression levels were determined by reverse transcription-quantitative polymerase chain reaction. ROR2 and Wnt5a protein and mRNA expression were significantly overexpressed in PTC tissues $(\mathrm{P}<0.05)$. The present study also revealed that ROR2 and Wnt5a were significantly associated with tumor stage and lymph node metastasis $(\mathrm{P}<0.05)$. There was a positive association between ROR2 and Wnt5a expression levels $(\mathrm{r}=0.857 ; \mathrm{P}=0.007)$. In conclusion, ROR2 and Wnt5a may act as tumor suppressor genes in the development of PTC; overexpression of ROR2 and Wnt5a in PTC may be important for tumorigenesis and tumor development.
\end{abstract}

\section{Introduction}

Thyroid cancer is the most common type of endocrine tumor; since 2000, overall thyroid cancer incidence rates have increased by $\sim 8 \%$ per year (1). Papillary thyroid carcinoma (PTC) is the major histological type and accounts for $\sim 80 \%$ of all thyroid types of cancer $(2,3)$. Highly effective for

Correspondence to: Professor Baoen Shan, Research Center, The Fourth Hospital of Hebei Medical University, 12 Jiankang Road, Shijiazhuang, Hebei 050011, P.R. China

E-mail: baoen_shan@163.com

Key words: tyrosine kinase-like orphan receptor 2, Wnt member 5a, papillary thyroid carcinoma, tumor the treatment of PTC involves surgery and radioactive iodine; however, the traditional therapies are ineffective against advanced radioactive iodine-resistant PTC. The majority of patients with PTC demonstrate excellent clinical outcomes; however, distant metastasis of PTC can be fatal (4).

Tyrosine kinase receptors represent targets of great interest for cancer therapy. The tyrosine kinase-like orphan receptor 2 (ROR2), is also a Wnt ligand receptor. ROR2 has been revealed to specifically interact with Wnt5a. Aberrant activation of Wnt signaling is involved in the development of various types of tumors $(4,5)$. In renal cell carcinoma, a high expression level of ROR2 demonstrated a significant association with higher clinical stage, nuclear grade and tumor stage (5). Recent data suggested that the Wnt signaling pathway also altered PTC with RET/PTC mutations (6). To the best of our knowledge, the present study revealed for the first time that ROR2 and Wnt5a expression levels may also be altered in PTC tissues compared with normal tissues.

The present study evaluated the protein expression levels of ROR2 and Wnt5a in human PTC and adjacent normal tissues, investigated the changes and clinical significance of ROR2 in PTC and its association with Wnt5a expression.

\section{Materials and methods}

Patients and samples. The present study utilized 58 human PTC tissues and paired adjacent noncancerous tissues excised from patients with histologically confirmed PTC between January 2014 and July 2015 at the Department of Oncological Surgery, Central Hospital of Cangzhou (Cangzhou, China). The tissue samples were frozen immediately in liquid nitrogen on removal from the patients. The present study was approved by the Ethics Committee of the Central Hospital of Cangzhou. Written informed consent was obtained from all patients prior to enrollment in the present study.

Immunohistochemistry analysis. The rabbit anti-human ROR2 polyclonal antibody (cat. no. SC-98486; 1:1,000) and the rabbit anti-human $\beta$-actin polyclonal antibodies (cat. no. SC-130656; 1:1,000) were purchased from Santa Cruz Biotechnology Inc. (Dallas, TX, USA). The rabbit anti-human 
Wnt5a polyclonal antibody (cat. no. 55184-1-AP; 1:1,000) was purchased from Abcam (Cambridge, UK). The tissues were fixed with $4 \%$ paraformaldehyde for $12 \mathrm{~h}$ and then embedded in paraffin and sliced into $4-\mu \mathrm{m}$ sections; these sections were then dewaxed in xylene for 3 min three times, $100 \%$ ethanol for $2 \mathrm{~min}$ three times, $95 \%$ ethanol for $2 \mathrm{~min}, 80 \%$ ethanol for $2 \mathrm{~min}, 70 \%$ ethanol for $2 \mathrm{~min}$ and PBS for $5 \mathrm{~min}$. Endogenous peroxidase activity was blocked by soaking slides in $3 \% \mathrm{H}_{2} \mathrm{O}_{2}$ for $15 \mathrm{~min}$ at room temperature (RT). The slides were then agitated and excess PBS removed. All tumor sections were circled with a PAP pen. A total of $75 \mu \mathrm{l}$ blocking buffer (Shanghai Xin Le Biological Technology Co., Ltd, Shanghai, China) was added to each section immediately. The slides were then incubated for $1 \mathrm{~h}$ to overnight at RT in a humidified chamber. The appropriate primary antibody was applied overnight at $4^{\circ} \mathrm{C}$. PBS-incubated slides were used as a negative control. Subsequent to washing in PBS three times, the tissue sections were incubated with biotin-conjugated secondary antibody (Goat anti-rabbit antibody; cat. no. ab6720; Abcam; $1: 1,000)$ at room temperature for $1 \mathrm{~h}$. Subsequently, the tissue sections were visualized using $0.05 \%$ diaminobenzidine in PBS for $5 \mathrm{~min}$ at $37^{\circ} \mathrm{C}$. The tissue sections were counterstained with hematoxylin (10\%) at room temperature for $1 \mathrm{~min}$, dehydrated using graded ethanol (70,80 and 100\%) and sealed and covered with glass coverslips. All slides were processed by the same pathologist.

Two independent pathologists reviewed all histological tissue sections and evaluated the immunohistochemistry staining results according to the criteria of the World Health Organization (7). The pathologists randomly observed 10 high power fields of view with 100 cells in each view using a light microscope at magnification, x400 (Olympus Corporation, Tokyo, Japan). Comprehensive evaluation was performed according to the intensity and percentage of the stained tumor cells. Staining intensity was graded according to the following criteria: 0 , no staining; 1 , yellow; 2 , deep yellow; and 3 , brown. The proportion of positive tumor cells was scored as follows: 0 , no positive tumor cells; $1,<10 \%$ positive tumor cells; $2,10-50 \%$ positive tumor cells; $3,51-80 \%$ positive tumor cells; and $4,>80 \%$ positive tumor cells. The immunohistochemical expression level was based on the total scores. Total score $=$ points of staining intensity + points of percentage of positive cells. The tissue samples were classified into two groups, as follows: Negative expression, 0-1 points; and positive expression, 2-6 points.

Western blot analysis. Proteins were extracted from nitrogen-frozen tissue fragments of tissue samples. The tissues were homogenized in $1 \mathrm{ml}$ radioimmunoprecipitation assay buffer (Beyotime Institute of Biotechnology, Haimen, China) and subsequently with protease inhibitor cocktail (Beyotime Institute of Biotechnology) at $0^{\circ} \mathrm{C}$ for $20 \mathrm{~min}$, followed by incubation for $20 \mathrm{~min}$ on ice and centrifugation at $12,000 \mathrm{x} \mathrm{g}$ for $15 \mathrm{~min}$ at $4^{\circ} \mathrm{C}$. Following collection of the supernatant fluid, the sample was boiled for $15 \mathrm{~min}$ then stored at $-80^{\circ} \mathrm{C}$. Proteins $(50 \mu \mathrm{g} /$ well) were separated by $8 \%$ SDS-PAGE. The absorbance of proteins at A562 nm was measured by a microplate reader. The protein concentration was calculated from the standard curve. Following electrophoresis, proteins were transferred to polyvinylidene
Table I. Analysis of ROR2 expression level in PTC and normal tissues.

\begin{tabular}{lccccc}
\hline & & \multicolumn{2}{l}{ ROR2 expression, $\mathrm{n}$} & & \\
\cline { 3 - 4 } Group & Cases, $\mathrm{n}$ & Negative & Positive & $\chi^{2}$ & P-value \\
\hline PTC & 58 & 22 & 36 & 5.829 & 0.016 \\
Normal & 58 & 35 & 23 & & \\
\hline
\end{tabular}

ROR2, tyrosine kinase-like orphan receptor 2; PTC, papillary thyroid carcinoma.

Table II. Analysis of Wnt5a expression level in PTC and normal tissues.

\begin{tabular}{lccccc}
\hline & & \multicolumn{2}{c}{ Wnt5a expression, $\mathrm{n}$} & & \\
\cline { 3 - 4 } Group & Cases, $\mathrm{n}$ & Negative & Positive & $\chi^{2}$ & P-value \\
\hline PTC & 58 & 19 & 39 & 15.211 & $<0.001$ \\
Normal & 58 & 40 & 18 & & \\
\hline
\end{tabular}

Wnt5a, Wnt member 5a; PTC, papillary thyroid carcinoma.

difluoride membranes and blocked for $1 \mathrm{~h}$ with $5 \%$ fat-free milk at room temperature. The membranes were incubated with primary antibodies, anti-ROR2 (SC-98486; 1:1,000) and anti-Wnt5a (55184-1-AP; 1:1,000), overnight at $4^{\circ} \mathrm{C}$. $\beta$-actin antibody (SC-130656; 1:1,000) was used as the loading control. Subsequently, the membranes were incubated with secondary antibody (horseradish peroxidase-conjugated antibodies) at room temperature for $1 \mathrm{~h}$ (goat anti-rabbit antibody; ab6721; Abcam, 1:1,000). Following three washes with TBS for $15 \mathrm{~min}$ at room temperature, the membranes were treated with a chemiluminescence detection kit (Pierce; Thermo Fisher Scientific, Inc., Waltham, MA, USA). Protein bands were quantified using densitometry (Gel-Doc Gel-It2 310 Imaging Analysis System, Bio-Rad Laboratories, Hercules, CA, USA).

RNA extraction and cDNA synthesis and reverse transcription-quantitative polymerase chain reaction ( $R T$ - $q P C R)$. Total RNA isolation and cDNA synthesis were performed as previously described (8). Total RNA of PTC tissues and paired adjacent noncancerous tissues were isolated using TRIzol ${ }^{\circledR}$ (Invitrogen; Thermo Fisher Scientific, Inc.), according to manufacturer's instructions. RNA quality and concentration were assessed on the NanoDrop 1000 (Thermo Fisher Scientific, Inc.). A total of $1 \mu \mathrm{g}$ RNA was reverse transcribed using the First-Strand cDNA Synthesis kit (Thermo Fisher Scientific, Inc.) with Oligo(dT) primer. PCR primers used were as follows: ROR2 forward, 5'-GGCAGAACCCATCCT CGTG-3' and reverse, 5'-CGACTGCGAATCCAGGACC-3'; Wnt5a forward, 5'-ACCACATGCAGTACATCGGAG-3' and reverse, 5'-GAGGTGTTATCCACAGTGCTG-3'; and GAPDH forward, 5'-GAAGGTGAAGGTCGGAGTC-3' and reverse, 
A

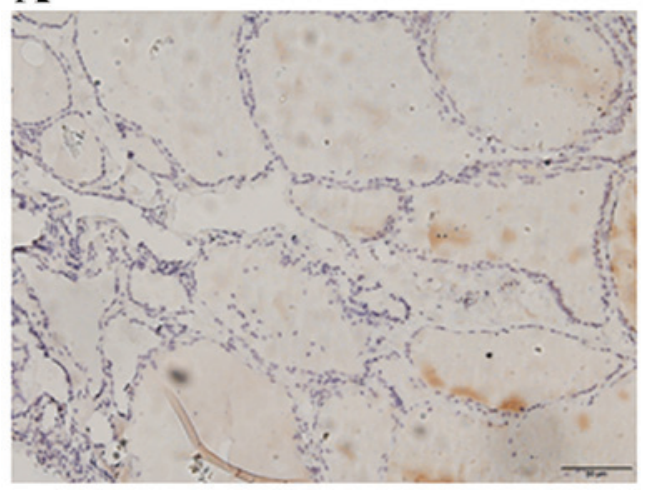

B

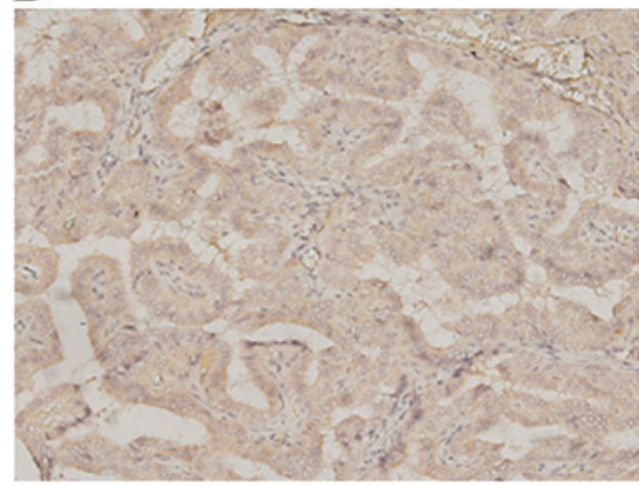

Figure 1. The expression level of tyrosine kinase-like orphan receptor 2 in (A) normal thyroid tissues and (B) papillary thyroid carcinoma tissues by immunohistochemistry (magnification, x200).

A

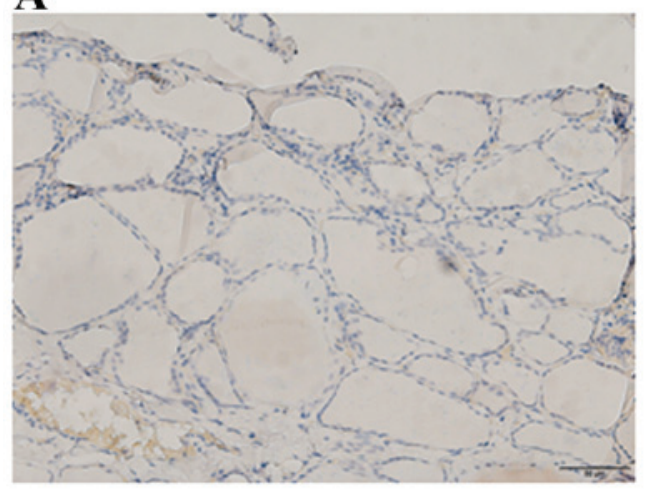

B

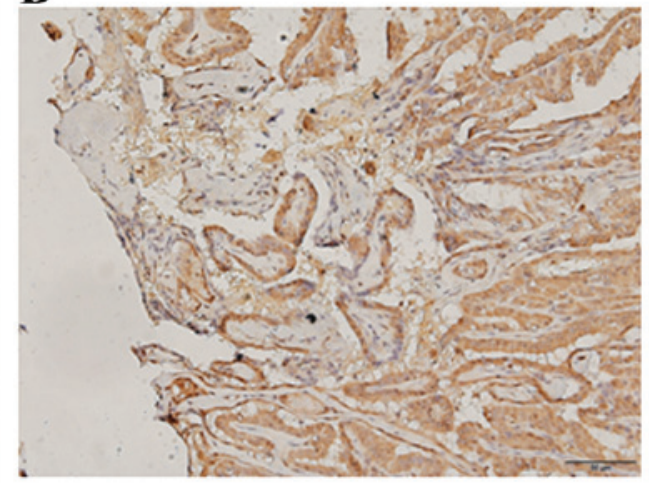

Figure 2. The expression level of Wnt member 5a in (A) normal thyroid tissues and (B) papillary thyroid carcinoma tissues by immunohistochemistry (magnification, x200).

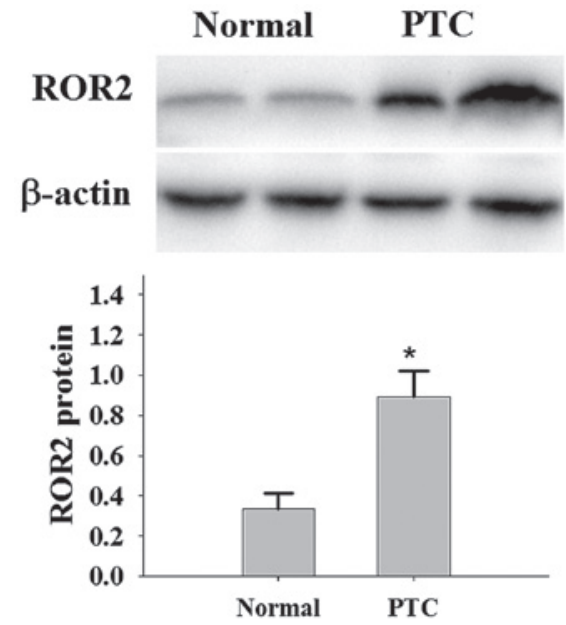

Figure 3. The expression level of ROR2 in PTC tissues and the corresponding normal tissues. A relatively high ROR2 protein expression level was revealed in PTC tissues compared with in normal thyroid tissues $\left({ }^{*} \mathrm{P}<0.05\right)$. ROR2, tyrosine kinase-like orphan receptor 2; PTC, papillary thyroid carcinoma.

5'-GAAGATGGTGATGGGATTTC-3'. The PCR reaction was performed for 40 cycles of a 3-step program: $95^{\circ} \mathrm{C}$ for $15 \mathrm{sec}$, annealing temperature at $60^{\circ} \mathrm{C}$ for $15 \mathrm{sec}, 72^{\circ} \mathrm{C}$ for $1 \mathrm{~min}$. mRNA levels were quantified using the $2^{-\Delta \Delta C q}$ method (9).
Statistical analysis. Statistical analysis was performed using SPSS version 13.0 (SPSS, Inc., Chicago, IL, USA). The expression level of mRNA was represented as fold change using the $2^{-\Delta \Delta C q}$ method. The $\chi^{2}$ test was performed to determine the association between protein ROR 2 expression level and clinicopathological features. $\mathrm{P}<0.05$ was considered to indicate a statistically significant difference.

\section{Results}

ROR 2 protein and Wnt5a protein expression is increased in $P T C$. The patients in this study comprised 43 females and 15 males with an age range of $16-57$ years. The present study selected the most representative PTC and adjacent normal tissues. Immunohistochemistry demonstrated that 36 patients exhibited positive expression of the ROR2 protein $(\mathrm{P}<0.05$; Fig. 1; Table I) and 39 patients exhibited positive expression of the Wnt5a protein $(\mathrm{P}<0.05$; Fig. 2; Table II). Western blot analysis demonstrated that the protein expression levels of ROR2 and Wnt5a in PTC were significantly increased compared with the expression in normal thyroid tissue samples (Figs. 3 and 4).

ROR2 gene and Wnt5a gene expression is increased in PTC. ROR2 and Wnt5a mRNA expression levels were significantly 
Table III. Association between ROR2 expression level and clinicopathological characteristics in patients with PTC.

\begin{tabular}{|c|c|c|c|c|c|}
\hline \multirow[b]{2}{*}{ Clinicopathological characteristics } & \multirow[b]{2}{*}{ Cases, $\mathrm{n}$} & \multicolumn{2}{|c|}{ ROR2 expression, $\mathrm{n}$} & \multirow[b]{2}{*}{$\chi^{2}$} & \multirow[b]{2}{*}{ P-value } \\
\hline & & Negative & Positive & & \\
\hline Age & & & & 0.648 & 0.421 \\
\hline$<45$ years & 20 & 9 & 11 & & \\
\hline$\geq 45$ years & 38 & 13 & 25 & & \\
\hline Sex & & & & 2.039 & 0.153 \\
\hline Male & 15 & 8 & 7 & & \\
\hline Female & 43 & 14 & 29 & & \\
\hline Tumor Stage & & & & 6.408 & 0.007 \\
\hline I, II & 40 & 20 & 20 & & \\
\hline III, IV & 18 & 2 & 16 & & \\
\hline Tumor size & & & & 0.741 & 0.389 \\
\hline$<1 \mathrm{~cm}$ & 41 & 17 & 24 & & \\
\hline$\geq 1 \mathrm{~cm}$ & 17 & 5 & 12 & & \\
\hline Lymph node involvement & & & & 5.084 & 0.028 \\
\hline Yes & 24 & 5 & 19 & & \\
\hline No & 34 & 17 & 17 & & \\
\hline Multifocal & & & & 0.056 & 0.814 \\
\hline Yes & 20 & 8 & 12 & & \\
\hline No & 38 & 14 & 24 & & \\
\hline
\end{tabular}

ROR2, tyrosine kinase-like orphan receptor 2; PTC, papillary thyroid carcinoma.

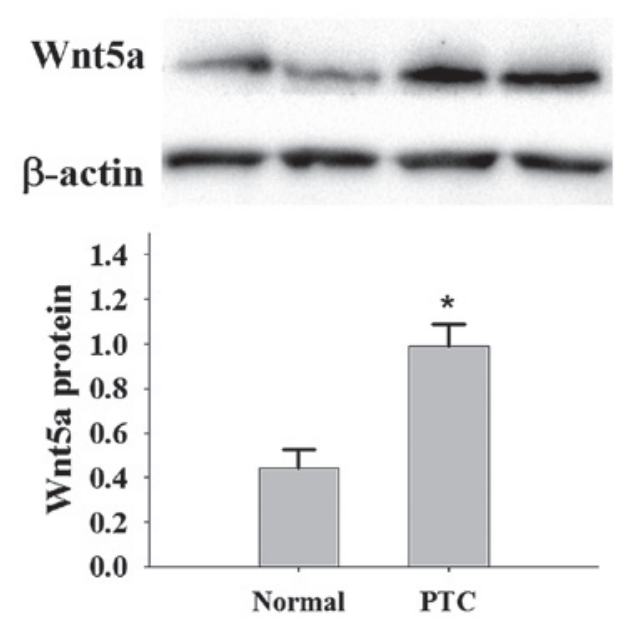

Figure 4. The expression levels of Wnt5a in PTC tissues and its counterpart normal tissues. Relatively high Wnt5a protein expression levels were revealed in PTC tissues compared with normal thyroid tissues $\left({ }^{*} \mathrm{P}<0.05\right)$. Wnt5a, Wnt member 5a; PTC, papillary thyroid carcinoma.

increased in PTC samples compared with in normal thyroid tissue samples (Figs. 5 and 6).

ROR2 and Wnt5a expression with pathological features. The expression level of ROR2 was associated with tumor stage and lymph node metastasis in PTC; however, there was no association with age, sex, tumor size and the number of tumors (Table III). Wnt5a was also associated with tumor stage and lymph node metastasis; no significant differences were

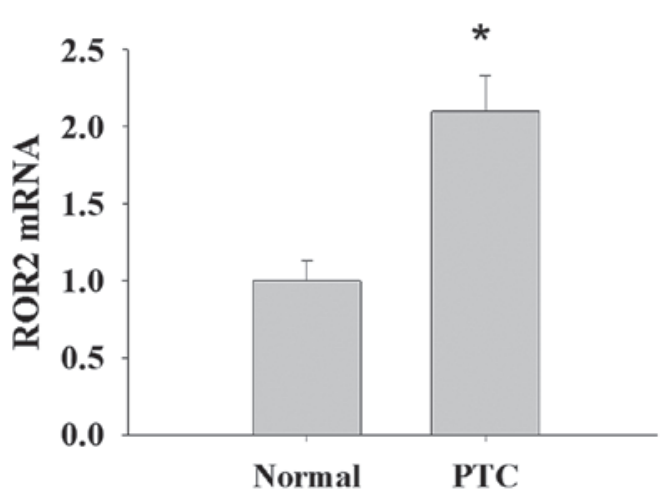

Figure 5. The expression levels of ROR2 mRNA in PTC tissues and its counterpart normal tissues were detected by reverse transcription-quantitative polymerase chain reaction ( $\mathrm{P}<0.05)$. ROR2, tyrosine kinase-like orphan receptor 2; PTC, papillary thyroid carcinoma.

identified between Wnt5a expression levels and other clinicopathological findings, including age, sex, tumor size and the number of tumors (Table IV).

Correlation between ROR2 and Wnt5a in PTC. There were significant positive associations between ROR2 and Wnt5a (Table V).

\section{Discussion}

Thyroid cancer incidence increased, on average, $3.6 \%$ per year during 1974-2013, this was primarily associated 
Table IV. Association between Wnt5a expression level and clinicopathological characteristics in patients with PTC.

\begin{tabular}{|c|c|c|c|c|c|}
\hline \multirow[b]{2}{*}{ Clinicopathological characteristics } & \multirow[b]{2}{*}{ Cases, $\mathrm{n}$} & \multicolumn{2}{|c|}{ Wnt5a expression, $\mathrm{n}$} & \multirow[b]{2}{*}{$\chi^{2}$} & \multirow[b]{2}{*}{ P-value } \\
\hline & & Negative & Positive & & \\
\hline Age & & & & 0.727 & 0.394 \\
\hline$<45$ years & 20 & 8 & 12 & & \\
\hline$\geq 45$ years & 38 & 11 & 27 & & \\
\hline Sex & & & & 0.482 & 0.488 \\
\hline Male & 15 & 6 & 9 & & \\
\hline Female & 43 & 13 & 30 & & \\
\hline Tumor Stage & & & & 7.069 & 0.003 \\
\hline I, II & 40 & 18 & 22 & & \\
\hline III, IV & 18 & 1 & 17 & & \\
\hline Tumor size & & & & 0.070 & 0.791 \\
\hline$<1 \mathrm{~cm}$ & 41 & 13 & 28 & & \\
\hline$\geq 1 \mathrm{~cm}$ & 17 & 6 & 11 & & \\
\hline Lymph node involvement & & & & 3.647 & 0.046 \\
\hline Yes & 24 & 4 & 20 & & \\
\hline No & 34 & 15 & 19 & & \\
\hline Multifocal & & & & 0.070 & 0.792 \\
\hline Yes & 20 & 7 & 13 & & \\
\hline No & 38 & 12 & 26 & & \\
\hline
\end{tabular}

Wnt5a, Wnt member 5a; PTC, papillary thyroid carcinoma.

Table V. Association between ROR2 and Wnt5a expression levels in PTC.

\begin{tabular}{lcc}
\hline Protein & r-value & P-value \\
\hline ROR2 & 0.857 & 0.007 \\
Wnt5a & & \\
\hline
\end{tabular}

Wnt5a, Wnt member 5a; PTC, papillary thyroid carcinoma; ROR2, tyrosine kinase-like orphan receptor 2.

with increases in PTC of $4.4 \%$ per year (10). The main treatment for PTC involves total or subtotal thyroidectomy, radioactive iodine and thyroid hormone inhibitory therapy; however, the traditional therapies are ineffective against advanced radioactive iodine-resistant PTC (11). The majority of patients with PTC have a favorable prognosis and asymptomatic long-term survival; however, invasion and metastasis is also one of the major causes of mortality in patients with PTC (12). The invasion and metastasis of PTC is an interactive effect mediated by diverse genes and factors $(13,14)$.

A previous study revealed that ROR 2 has a role in cell migration and invasion $(15,16)$. ROR2 is a transmembrane protein and acts as a Wnt ligand receptor that participates in Wnt signaling (17). A previous study suggested that ROR2 mediates Wnt5a signaling in a variety of tumor types,

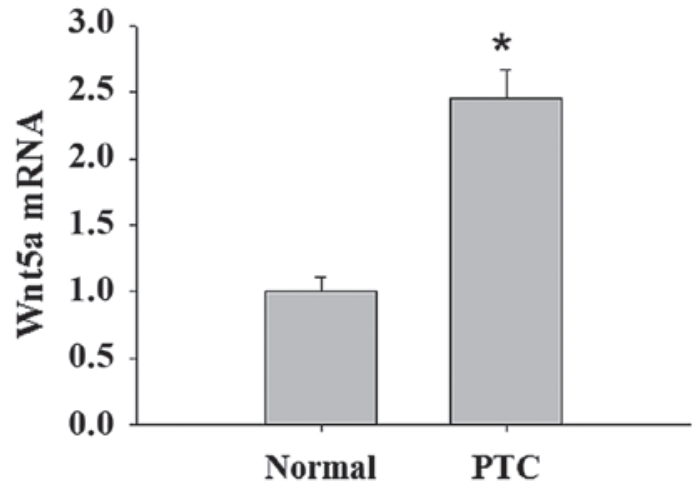

Figure 6. The expression levels of Wnt5a mRNA in PTC tissues and corresponding normal tissues were detected by reverse transcription-quantitative polymerase chain reaction $\left({ }^{*} \mathrm{P}<0.05\right)$. Wnt5a, Wnt member 5a; PTC, papillary thyroid carcinoma.

including in human metastatic melanoma, leiomyosarcoma and gastrointestinal stromal tumors, renal cell carcinoma and osteosarcoma (8,18-21). Although it is accepted that altered Wnt signaling is a late event in thyroid cell transformation that affects anaplastic thyroid tumors, previous data suggested that it is also altered in PTC with RET/PTC mutations (22). The present study inferred that ROR2 and Wnt5a may also have an important role in PTC.

The present study demonstrated that ROR2 and Wnt5a protein translation and gene transcription were upregulated in PTC tissues in comparison with the matched adjacent 
normal thyroid tissues. ROR2 is a member of a family of proteins known as receptor protein kinases, which have a key role in cell growth, differentiation and cell movement. Wnt5a binds to its receptor ROR2 and activates a serine/threonine-specific protein kinase, CamKII, which negatively regulates the canonical Wnt/ $\beta$-catenin signaling via the MAPK signaling pathway. An association was revealed between ROR2 expression level and tumor stage as well as lymph nodes metastasis. Wnt5a protein expression level was observed to be increased more significantly in patients with advanced stage and lymph node metastases; however, the role of the Wnt5a/ROR2 signaling pathway in cancer remains unknown (23). Wnt5a was demonstrated to signal via ROR2 to induce cellular migration and invasion in murine fibroblast NIH3T3 cells (24). Wright et al (21) demonstrated that ROR2 promotes tumor growth potential in renal cell carcinoma. McDonald and Silver (23) revealed that in cancer cells, the oncogenic potential of ROR2 may be conferred by Wnt5a via the promotion of cancer cell invasion. In the present study, compared with in the normal thyroid tissues, the expression level of ROR2 and Wnt5a in PTC tissues was increased markedly; therefore, ROR2 and Wnt5a may be involved in the progress of PTC or may become additional tumor markers for the diagnosis of PTC. However, it remains unclear how the Wnt5a/ROR2 signaling pathway acts in PTC.

The present study investigated the clinical significance of ROR2 and Wnt5a in patients with PTC for the first time and the result demonstrated that ROR2 and Wnt5a were significantly upregulated in PTC tissues compared with in the matched adjacent normal thyroid tissues. High ROR2 and Wnt5a expression levels were associated with tumor stage and lymph node metastases. Furthermore, there was a significant positive association between ROR 2 and Wnt5a expression levels. These results indicated the cancer-promoting activity of the Wnt5a/ROR2 signaling pathway in PTC tissues. Rasmussen et al (6) revealed that in patients with renal cell carcinoma a high expression level of ROR2 was associated with a significantly lower overall survival rate, cancer specific survival and recurrence free survival compared with renal cell carcinoma patients with low expression levels of ROR2; these findings suggested that ROR2 may be considered as a negative prognostic biomarker and potential therapeutic target in this type of cancer. A study investigating cervical cancer indicated that ROR2 was significantly associated with cancer progression and poor prognosis (25). Lara et al (26) demonstrated that epigenetic alteration of ROR2 has a Wnt-mediated, pro-tumorigenic role in colon cancer. In brief, ROR 2 with Wnt5a may have an important role in the infiltration and metastasis of PTC.

In summary, compared with normal thyroid tissues, the present study revealed a high expression level of ROR2 and Wnt5a in PTC tissues. Furthermore, the expression levels of ROR2 and Wnt5a were associated with tumor stage and lymph node metastasis. There was a significant positive association between ROR2 and Wnt5a expression levels. The results of the present study indicated that the Wnt5a/ROR2 signaling pathway may have a critical role in driving cell proliferation and migration. The expression level of ROR2 and Wnt5a mRNA significantly increased with tumor progression, which suggested that the ROR2 and Wnt5a genes have potential as targets for cancer gene therapy. In conclusion, these results indicated that ROR2 and Wnt5a may be promising biomarkers and potential therapeutic targets for PTC in the future.

\section{References}

1. Haugen BR, Alexander EK, Bible KC, Doherty GM, Mandel SJ, Nikiforov YE, Pacini F, Randolph GW, Sawka AM, Schlumberger M, et al: 2015 American thyroid association management guidelines for adult patients with thyroid nodules and differentiated thyroid cancer: The American thyroid association guidelines task force on thyroid nodules and differentiated. Thyroid 26: 1-133, 2016.

2. La Vecchia C, Malvezzi M, Bosetti C, Garavello W, Bertuccio P, Levi F and Negri E: Thyroid cancer mortality and incidence: A global overview. Int J Cancer 136: 2187-2195, 2015.

3. Zimmermann MB and Galetti V: Iodine intake as a risk factor for thyroid cancer: A comprehensive review of animal and human studies. Thyroid Res 8: 8, 2015.

4. Jeon MJ, Kim WG, Choi YM, Kwon H, Lee YM, Sung TY, Yoon JH, Chung KW, Hong SJ, Kim TY, et al: Features predictive of distant metastasis in papillary thyroid microcarcinoma. Thyroid 26: 161-168, 2016.

5. Lara E, Calvanese V, Huidobro C, Fernández AF, Moncada-Pazos A, Obaya AJ, Aguilera O, González-Sancho JM, Sánchez L, Astudillo A, et al: Epigenetic repression of ROR2 has a Wnt-mediated, pro-tumourigenic role in colon cancer. Mol Cancer 9: 170, 2010.

6. Rasmussen NR, Debebe Z, Wright TM, Brooks SA, Sendor AB, Brannon AR, Hakimi AA, Hsieh JJ, Choueiri TK, Tamboli P, et al: Expression of Ror2 mediates invasive phenotypes in renal cell carcinoma. PLoS One 9: e116101, 2014.

7. International Agency for Research on Cancer: World Health Organization Classification of Tumours: Pathology and Genetics of Tumours of Endocrine Organs. DeLellis RA, Lloyd VR, Heitz PU and Eng C (eds). IARC Press, Lyon, France. Vol. 8. 3rd edition. pp320, 2004.

8. Sastre-Perona A and Santisteban P: Role of the wnt pathway in thyroid cancer. Front Endocrinol (Lausanne) 3: 31, 2012.

9. Livak KJ and Schmittgen TD: Analysis of relative gene expression data using real-time quantitative PCR and the 2(-Delta Delta C(T)) method. Methods 25: 402-408, 2001.

10. Lim H, Devesa SS, Sosa JA, Check D and Kitahara CM: Trends in thyroid cancer incidence and mortality in the United States, 1974-2013. JAMA 317: 1338-1348, 2017.

11. La Greca A, Xu B, Ghossein R, Tuttle RM and Sabra MM: Patients with multifocal macroscopic papillary thyroid carcinoma have a low risk of recurrence at early follow-up after total thyroidectomy and radioactive iodine treatment. Eur Thyroid J 6: 31-39, 2017.

12. Carhill AA, Litofsky DR, Ross DS, Jonklaas J, Cooper DS, Brierley JD, Ladenson PW, Ain KB, Fein HG, Haugen BR, et al: Long-term outcomes following therapy in differentiated thyroid carcinoma: NTCTCS registry analysis 1987-2012. J Clin Endocrinol Metab 100: 3270-3279, 2015.

13. Cerutti JM, Latini FR, Nakabashi C, Delcelo R, Andrade VP, Amadei MJ, Maciel RM, Hojaij FC, Hollis D, Shoemaker J and Riggins GJ: Diagnosis of suspicious thyroid nodules using four protein biomarkers. Clin Cancer Res 12: 3311-3318, 2006

14. Zou M, Baitei EY, Alzahrani AS, BinHumaid FS, Alkhafaji D, Al-Rijjal RA, Meyer BF and Shi Y: Concomitant RAS, RET/PTC, or BRAF mutations in advanced stage of papillary thyroid carcinoma. Thyroid 24: 1256-1266, 2014.

15. Henry C, Llamosas E, Knipprath-Meszaros A, Schoetzau A, Obermann E, Fuenfschilling M, Caduff R, Fink D, Hacker N, Ward R, et al: Targeting the ROR1 and ROR2 receptors in epithelial ovarian cancer inhibits cell migration and invasion. Oncotarget 6: 40310-40326, 2015.

16. Kim YH, Choi YW, Han JH, Lee J, Soh EY, Park SH, Kim JH and Park TJ: TSH signaling overcomes B-RafV600E-induced senescence in papillary thyroid carcinogenesis through regulation of DUSP6. Neoplasia 16: 1107-1120, 2014.

17. Cheung R, Kelly J and Macleod RJ: Regulation of villin by wnt5a/ror2 signaling in human intestinal cells. Front Physiol 2: $58,2011$. 
18. O'Connell MP, Fiori JL, Xu M, Carter AD, Frank BP, Camilli TC, French AD, Dissanayake SK, Indig FE, Bernier M, et al: The orphan tyrosine kinase receptor, ROR2, mediates wnt5A signaling in metastatic melanoma. Oncogene 29: 34-44, 2010.

19. Edris B, Espinosa I, Mühlenberg T, Mikels A, Lee $\mathrm{CH}$ Steigen SE, Zhu S, Montgomery KD, Lazar AJ, Lev D, et al: ROR2 is a novel prognostic biomarker and a potential therapeutic target in leiomyosarcoma and gastrointestinal stromal tumour. J Pathol 227: 223-233, 2012.

20. Wright TM and Rathmell WK: Identification of Ror2 as a hypoxia-inducible factor target in von hippel-lindau-associated renal cell carcinoma. J Biol Chem 285: 12916-12924, 2010.

21. Wright TM, Brannon AR, Gordan JD, Mikels AJ, Mitchell C, Chen S, Espinosa I, van de Rijn M, Pruthi R, Wallen E, et al: Ror2, a developmentally regulated kinase, promotes tumor growth potential in renal cell carcinoma. Oncogene 28: 2513-2523, 2009.

22. Enomoto M, Hayakawa S, Itsukushima S, Ren DY, Matsuo M, Tamada K, Oneyama C, Okada M, Takumi T, Nishita M and Minami Y: Autonomous regulation of osteosarcoma cell invasiveness by Wnt5a/Ror2 signaling. Oncogene 28: 3197-3208, 2009.
23. McDonald SL and Silver A: The opposing roles of Wnt-5a in cancer. Br J Cancer 101: 209-214, 2009.

24. Nomachi A, Nishita M, Inaba D, Enomoto M, Hamasaki M and Minami Y: Receptor tyrosine kinase Ror2 mediates Wnt5a-induced polarized cell migration by activating c-Jun $\mathrm{N}$-terminal kinase via actin-binding protein filamin A. J Biol Chem 283: 27973-27981, 2008.

25. Sun B, Ye X, Lin L, Shen M and Jiang T: Up-regulation of ROR2 is associated with unfavorable prognosis and tumor progression in cervical cancer. Int J Clin Exp Pathol 8: 856-861, 2015.

26. Lara E, Calvanese V, Huidobro C, Fernández AF Moncada-Pazos A, Obaya AJ, Aguilera O, González-Sancho JM, Sánchez L, Astudillo A, et al: Epigenetic repression of ROR2 has a Wnt-mediated, pro-tumourigenic role in colon cancer. Mol Cancer 9: 170, 2010 